\title{
Study on the Problems and Countermeasures of Constructing Port Economic Circle in Ningbo
}

\author{
Hang ZHAO \\ Finance and Trade College \\ Ningbo Dahongying University \\ Ningbo, China
}

\author{
An-ji ZHU \\ Finance and Trade College \\ Ningbo Dahongying University \\ Ningbo, China
}

\author{
Ling-ling ZUO \\ Finance and Trade College \\ Ningbo Dahongying University \\ Ningbo, China
}

\begin{abstract}
Ningbo made the "port economic circle" important decision-making in line with the strategy" the Belt and Road". Based on the analysis of the connotation of "port economic circle", it is considered that the construction of "port economic circle" will enhance the national strategic status of Ningbo, promote the internationalization of Ningbo city, enhance its core position in East China, the smooth implementation of national strategies and interpretation of marine power strategy has important value. The article points out that there are some bottlenecks in Ningbo's strategy of "port economic circle", which is manifested in the fuzzy nature of the construction of "port economic circle". The foothold of port economic circle is narrow, Port economic circle has a limited perspective, and "port economic circle" has a range of instability and so on. In view of the existing problems, the paper puts forward some countermeasures.
\end{abstract}

Keywords-Port Economic Circle; Ningbo; Problems; Countermeasures

\section{INTRODUCTION}

Ningbo port is the largest resources, over the years, Ningbo always adhere to the "development strategy of Ningbo port and Ningbo city with each other and promote common prosperity ", speed up the building of international port, and achieved the throughput of the port container throughput of fourth in the world, fifth of the world's outstanding performance. At present, facing the new economic norm, Ningbo will continue to make a fuss around the port, actively docking the major development strategy of international "The Belt and Road" and the Yangtze River economic belt construction, put forward to create a positive influence in eastern China, the Yangtze River Delta economic circle to port, let the port economic circle has become the new power of leading the economy in Ningbo. The construction of the port economic circle is the most important task of the government of Ningbo City, and has received extensive attention and positive response from various departments and governments at all levels.

\section{THE CURRENT PROBLEMS FACED BY THE CONSTRUCTION OF NingBo PORT ECONOMIC CIRCLE}

\section{A. Port function is not perfect}

One is the port system is not perfect, railway, airport transportation, inland transportation system is still in the "legs", which only accounted for $7.6 \%, 15.5 \%$ and $6.9 \%$. Two is the port service added value is not high, mainly in the handling and transfer function, trade, logistics services and other functions is still in the initial stage. Shipping finance, shipping insurance, shipping brokerage, maritime law, shipping information and consulting services and other high value-added industries development lag. The three is the port development space is limited, port industry, trade and logistics industry scattered layout, industry cluster function is not outstanding, has yet to give full play to promote each other, the port industry and city development.

\section{B. The effect of urban radiation is not obvious}

Ningbo as the economic center of the south of Yangtze River Delta, Shaoxing, Taizhou, Zhoushan around the city of Jiaxing, the driving force is not strong, especially in the highend talent, advanced technology, capital and other aspects. And the surrounding cities have failed to discipline from Ningbo's industrial transfer and industrial facilities.

\section{Competition is fierce in the surrounding ports}

Ningbo port and Shanghai port, Zhoushan port in the Yangtze River Delta region, in the hinterland of resources are staggered and even overlap, intense competition, similar lack of complementary energy wharf, coastal resources scientific phenomenon is more prominent, there is a big gap between the policy and the Shanghai free trade zone and the Zhoushan New District, Hong Kong and Zhoushan, along the Yangtze River port in Hong Kong, overseas investment, management, technology and other aspects is not closely linked. 


\section{The industrial structure needs to be improved}

In the industrial division of labor system, Ningbo most industrial enterprises are still in the low end of the production status. High and new technology industry overall at the lower end of value chain, strategic emerging industry scale is not big enough. And still exists certain gaps when compared with other cities, the industrial structure needs to be further strengthened.

\section{COUNTERMEASURES AND SUGGESTIONS OF ACCELERATING THE CONSTRUCTION OF NingBo PORT ECONOMIC CIRCLE}

\section{A. Improving port transportation network, the construction of the international hub port}

After many years of development, Ningbo port has established the strategic position of China's deep-water hub port and international container ocean route. In 2014, Ningbo port cargo throughput and container throughput were ranked third in the mainland of China port. Ningbo in the construction of the international hub port in the process still needs to improve port infrastructure and transportation network, to further expand the port radiation, to be connected to "The Belt and Road" and the Yangtze River economic belt is an important hub port. One is to promote the construction of port infrastructure. Optimization of the development and utilization of coastal resources, building a number of container and bulk cargo terminal facilities, improve channel anchorage, enhance the bearing capacity of the port. Two is the construction of land transportation network interconnection. Actively open up new routes, improve the route network of Ningbo to the world, to build the Yangtze River Delta International Logistics hub. Start the Ningbo railway construction, actively planning the construction of Shanghai and Ningbo cross sea railway, improve the railway transportation network. To promote the construction of Meishan Port Road, six cross Hangzhou Ningbo high-speed railway, Ningbo Taiwan high-speed railway, to build a "ring ten shot four port highway network. The implementation of the project to promote the construction of Inland River, the operation area, enhances the ability to land the sea. Three is to develop multimodal transport. To strengthen the Yangtze River economic belt and the Midwest hinterland development, vigorously develop the rail transport, Jianghai transport and multimodal transport, Jianghai transport service center construction land; build Ningbo - East China Sea rail container transportation "golden channel". To promote the "Yongxin Europe" trade logistics line construction, enhancement of Central Asia, Europe and other regions of import and export goods attract.

\section{B. To promote the innovation and development of the port industry}

At present, Ningbo has become an important industrial base in East China region and the eastern coastal areas of China port logistics center, but the leading role of port to regional economy is not strong enough, Lingang Economic Development there is a great space and potential. Ningbo port should actively promote the optimization and upgrading of industrial structure; vigorously develop port service industry, new port industry, marine high-tech industry and other advantages of the industry, foster industrial clusters with international competitiveness. First, vigorously develop the modern logistics industry. With an eye to the strategic transformation of the transportation to the port of trade and logistics; the shipping logistics industry to the modernization and the high-end development, expand the area of port logistics services, to introduce and cultivate a number of port logistics operators, construction function of commodity trading, warehousing management, and electronic payment in one of the port logistics supply chain management service system. Port commodity distribution center to play the advantages, bigger and stronger liquid chemical industry, plastics, non-ferrous metals, iron ore, grain and oil and other trading varieties, the construction of the impact of commodity trading market. Perfect the shipping trading platform, fostering the growth of ship trading, shipping booking, transportation, liquid chemical ship crew training, logistics, shipping insurance and other characteristics of shipping service industry, the establishment of the "maritime Silk Road" information service platform, gradually enhance the ability to participate in international shipping resource allocation. Two is to promote high-end industrial port. The port industry is an important pillar of the economy of Ningbo. To continue the preferential development of port industry, industrial development oriented adhere to ecological, high-end, cluster, aimed at the petrochemical related industries, high-end equipment manufacturing industry and the national major project layout, build a number of strong radiation, strong power, high value-added industry cluster advantages, promote the upgrading of industrial structure. The three is to build the port industry development platform. Promote the construction of Ningbo Hangzhou Bay Industrial Zone, Ningbo Daxie Development Zone, Ningbo new material science and technology city regional development focus, concentrate on the introduction and cultivation of a number of international advanced level of the industry, to build the core competitiveness with the high-end industrial base. Play the unique advantages of marine economy, start the construction of Ningbo international marine ecological science and Technology City, improve the international high-end industrial layout planning, build regional innovation and development heights.

\section{To play a leading role in the opening of the port and expand the international trade and economic cooperation and cultural exchanges}

Ningbo should give full play to the role of leading and supporting port, and two-way open sea, open model of innovation, to enhance Ningbo Silk Road Economic Belt and twenty-first Century Maritime Silk Road support capabilities, to build the Yangtze River Economic Belt important open portal. One is to strengthen international and domestic port cooperation. Start the declaration of the Silk Road countries port cooperation organization, for the establishment of a permanent establishment, strengthen flights and shipping pricing, information sharing, coordination and cooperation of port construction. Deepen the province and coastal ports, along the Yangtze River port cooperation. Two is to promote the development of international investment and trade. Firmly grasp the favorable opportunity of international industrial transfer and the global market to re layout, increase investment 
in major industries, the introduction of a number of large projects in line with industrial development oriented projects. To encourage enterprises to "go out", the establishment of overseas resources development, production and processing and marketing base, strengthen investment and trade and capital technology cooperation The Belt and Road along the country, strengthen the transnational operating capabilities. Three is to build a high-level international economic and trade cooperation platform. Run China - Central and Eastern European countries investment and trade fair. The establishment of the ASEAN import products bonded display trading platform, imported goods distribution center. Organize the forum of Chinese and European ministers, China Navigation day, at home and abroad, "Ningbo week" and other major events. Four is to strengthen international cultural exchanges and cooperation. Tap the human resources of Ningbo, strengthen the promotion of city image, show the charm of Ningbo humanities, and improve the city's international visibility and influence. The development of "twenty-first Century Maritime Silk Road tourism brand, open cruise homeport routes, to create high-quality tourist routes, expand personnel exchanges.

\section{To strengthen the reform and innovation, activate the new power of the coordinated development of port economic circle}

Establishing the idea of cooperation and mutual benefit, promoting the regional coordinated development is the inherent requirement and important way for the construction of Ningbo port economic circle. To promote institutional innovation, and actively participate in cooperation and exchanges in the Yangtze River Delta, deepen strategic cooperation between the Yangtze River Economic Belt city, take the road of coordinated development. One is to deepen institutional reform of port logistics development. Actively plan the construction of the sea rail transport comprehensive test area, the establishment of a sound sea rail seamless convergence, information sharing, and customs clearance, freight consultation regulation of the development of new mechanisms for sea and rail transport. To promote the comprehensive reform of port service, strive for the port of shipment (station) tax, international ship registration, and coastal carrying pilot policy, innovation of shipping development system and mode of operation. Two is to deepen the reform of international trade facilitation. Learn from Shanghai Free Trade Zone, to promote investment and trade facilitation, financial internationalization, shipping development system innovation and other aspects of the experience and practice, to create an international and legal business environment. Play open port functions, planning and construction of Meishan trade facilitation test area, to explore overseas goods, funds, free import and export of the park system and policy, construction and international integration of the first district. Deepen the reform of large clearance, promote the Yangtze River Economic Belt customs clearance integration and inspection and quarantine reform, promote the port law enforcement departments to share information system, strengthen the construction of a single window. Three is to deepen the national cross-border e-commerce service pilot reform. Strengthen the daily consumer goods and commodities of cross-border electronic business platform construction, deepen the reform of supervision mode, electronic payment, credit system, tax rebate settlement etc., and build the test area of cross-border e-commerce with national influence.

\section{E. Build interconnection of land and sea collection and transportation network, deepen cooperation with the port at home and abroad, expand the port radiation.}

Build interconnection Jianghai land transport service center, Ningbo port infrastructure to strengthen support. Improve the comprehensive traffic system of Jianghai railway and railway transportation, establish the logistic information network of sharing docking, and establish an efficient logistics cooperation mechanism.

Strengthen the industry in high-end cooperation, the release of Ningbo port industry with impetus. Industry cooperation is an important connotation of the port economic circle. Based on the industrial advantages of Ningbo, aiming at the market demand of the circle domain city, the port industry will be turned out and the harbor service traction will be improved.

Expand economic and trade and cultural exchanges and cooperation, the formation of a new round of high-level opening up of Ningbo's international influence. Strengthen cooperation in international trade, science and technology, education, medical treatment, tourism and humanities, strengthen opening-up, widen the open area, enhance the level of opening up, raise the level of international trade development and build a number of high-level national economic and trade cooperation platform.

Strengthen reform and innovation, activation of Ningbo port economic circle collaborative development of new impetus. The reform and innovation throughout the port economic circle construction of the whole process strengthen the system design and innovation, for key areas, the key chain, the weak link reform to achieve substantive breakthrough. Promote the reform of international trade facilitation, strive for comprehensive pilot reform of international shipping services, and deepen the reform of national pilot cross-border ecommerce.

\section{CONCLUSION}

Through the above research, we can draw the conclusion: "the Belt and Road Initiative" provides a rare historical opportunity for the construction of the port economic circle of Ningbo. The construction of Ningbo has a profound historical background and distinctive significance of port economic circle, Ningbo should give full play to the port and port, richly endowed by nature, resources, marine ecology, economic Integration Bridge will complement each other's strengths, and actively create radiation, East China's Yangtze River Delta, influence the port economic circle. The construction of Ningbo port economic circle is an important starting point for the implementation of major strategic national and Zhejiang Province. Constructing the Ningbo port economic circle is an objective need to promote the internationalization of the city, expand the opening to the outside world, expand development space, is the important breakthrough to Ningbo to promote the 
development of innovation and transformation, striving for the comparative advantage and competitive advantage, but also a realistic option for Ningbo to enhance the function of resource allocation and the city's strategy position.

\section{REFERENCES}

[1] The people's Government of Ningbo Municipal Committee of the CPC Ningbo city [3]. About continuing to expand effective investment to promote higher quality of economic and social development of the opinions of [Z]. Party of Ningbo No. [2012]155.

[2] Ningbo Municipal Bureau of statistics.2015 Ningbo statistical yearbook [Z]. Beijing: China Statistics Press, 2015

[3] Zou Xiangyang, Zhu Xianping. China - Central Asia New Silk Road Economic Development Zone conception [J]. Northeast Asia Forum, 2006 (5).34.

[4] Xu Shaofeng. China's capital "going out" times gradually line asymptotic [J]. financial times, 2014

[5] C. K. Prahalad, Gary Hamel, The Core Competence of The Corporation [J], 2008(4)

[6] Matthew Brian Malchow. An Analys is of Port Selection[C]. Engineering-Civil and Environmental, 2008 